\title{
環境と経済の両側面を考慮したセメントおよびコンクリートの評価 EVALUATION OF ENVIRONMETAL AND ECONOMIC ASPECTS OF CEMENT AND CONCRETE
}

\author{
新見龍男*1, 桐野裕介*2, 加藤弘 義*3, 河 合研 至*4 \\ Tatsuo SHINMI, Yusuke KIRINO, Hiroyoshi KATO \\ and Kenji KAWAI
}

\begin{abstract}
To achieve SDGs, corporate activities considering environmental aspects are required, while evaluation using an economic indicator is also necessary for decision-making. The present study investigated the environmental impacts of cement and concrete considering economic aspects and calculated the full cost as the sum of the LCA cost and LCC. As a result, for both cement and concrete, the full cost for ordinary portland cement was lower than that for portland blast-furnace slag cement type B. For concrete using portland blast-furnace slag cement, the increase in the slag content increased the full cost of the cement.
\end{abstract}

Keywords : Waste indicator, Full cost, LCA cost, LCC, Portland cement, Portland blast-furnace slag cement 廃棄物指標，フルコスト，LCA コスト，LCC，ポルトランドセメント，高炉セメント

\section{1. はじめに}

2015 年の国連サミットにおいて, グローバルな社会課題を解決し 持続可能な世界を実現するための国際目標である SDGs（持続可能 な開発目標 : Sustainable Development Goals）が採択された。世 界中の企業が SDGs を経営の中に取り込もうと力を注いでおり, 日 本においても SDGs を経営に組み込むべく様々な取組みが進められ ている 1)。SDGs 達成のためには, 社会や環境に配慮した企業活動 が求められ，多くの企業においてライフサイクルアセスメント（以 下，LCA）が実施されている。

しかしながら，LCA による評価結果は環境側面に関する情報のみ であり, 企業活動の意思決定には経済側面の情報が必須となること から, 評価結果が企業活動の意思決定に直結しないとされている2)。

一方, 経済的側面の評価としてライフサイクルコスト (以下, LCC) が注目されている。LCC とは, 製品やシステム, 建築物などの誕生 から廃棄に至るまでに掛かる費用の総額であり ${ }^{3)}$, LCA の実施方法 の多くを LCC 算出に活用することが出来る ${ }^{2)}$ 。また, 初期コストだ けでなくランニングコストまで考慮して長期的な経済性を評価する ことから, 企業活動において最適な意思決定を行うことが可能とな る。そのため, LCC と LCA を総合的に評価することが, SDGs の 達成に向けて重要であると考えられる。

過去の研究においては, LCA の結果を経済価值に換算した LCA コストとして, LCC と総合的に評価した報告がなされており, 評価
対象は IC パッケージ 4), 途上国における浄水器の利用 5), 電気製品 の省エネ化 ${ }^{6}$ など多様である。一方で建設産業は地球環境に多大な 影響を及ぼすものの，LCA コストに関する評価は少なく，LCC と の関係性を評価した知見も少ない。そのため，建設費に及ぼす環境 影響の程度は不明な点が多い。

セメント産業における主要な環境影響はリサイクル資源（廃棄 物・副産物）の活用と $\mathrm{CO}_{2}$ 排出が挙げられる。しかしながら, セメ ントの環境影響評価は $\mathrm{CO}_{2}$ 排出量の観点のみで実施されることが 多く,リサイクル資源の活用を考慮した評価はほとんど見られない。 筆者らはこれまで，セメント製造におけるリサイクル資源活用を評 価する廃棄物指標を提案するとともに ${ }^{7}, \mathrm{CO}_{2}$ 排出量を含めたセメ ントの主要な環境影響を総合的かつ簡便に評価するための方法も提 案した 8)。また, 構造物のライフサイクルとしてセメントの製造か ら構造物の解体・廃棄までの LCA を実施した 9)。なお, 統合化評価 を実施するにあたっては, 日本版被害算定型影響評価手法の最新版 である LIME3 の統合化係数を用い, 経済指標として評価值を算出 した。その結果, 普通ポルトランドセメント（以下，PC）の方が混 合セメントである高炉セメント B 種（以下， BB） やフライアッシ ユセメント B 種より評価值が高いことが示された。しかしながら， 解体後のコンクリート塊の廃棄に関する負荷が著しく大きくなり, コンクリート塊のリサイクル率 $99 \%$ を考慮すると環境負荷を過大 評価しているとも考えられたため, 評価方法には課題が残った。

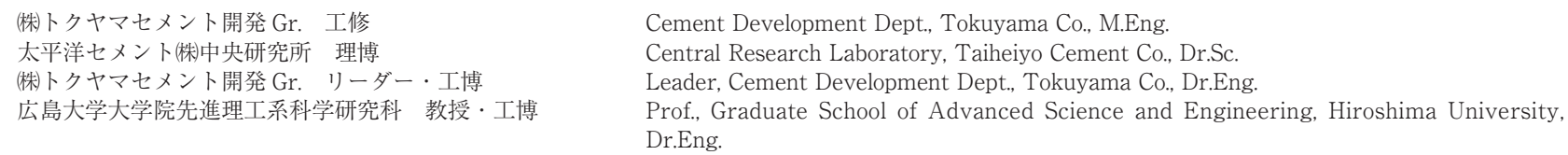




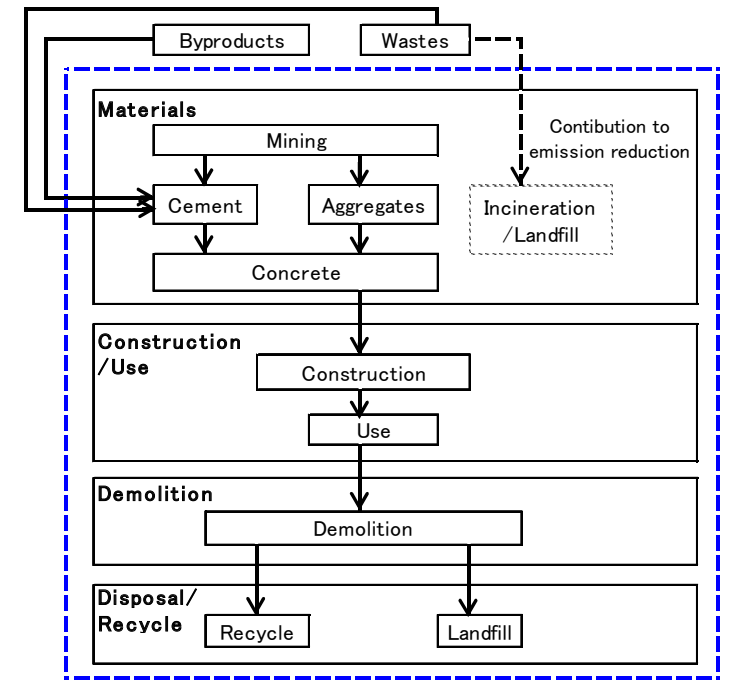

Fig. 1 System boundary in the previous study

そこで本検討では，コンクリート構造物の LCA に関してコンク リート塊の解体・廃棄に関する評価方法を再検討するとともに, セ メントおよびコンクリートについて経済影響を考慮した LCA を実 施し，LCC と LCA コストの関係性を示すことを目的とした。

\section{2. 評価方法の概要}

\section{1 廃棄物指標}

循環型社会の構築のためにはリサイクル資源を多量に活用するこ とが望まれている。一方, リサイクル資源の中でも, 比較的容易に 活用できる資源と活用が困難な資源が存在しており, 前者は比較的 広い産業で活用できるが, 後者は限られた産業でしか活用できない と考えられる。そのため, 後者の活用をより優先的に進めることに よって, 社会全体でのリサイクル資源の活用が進むことが予想され る。これを踏まえ, 筆者らはリサイクル資源の活用の困難さを反映 した廃棄物指標 $I W_{4}$ を提案した ${ }^{7)}$ 。

本指標は，複雑な前提条件がなく，セメント製造時に使用される リサイクル資源および製造時に発生するリサイクル資源のそれぞれ の原単位を用いて算出可能としている。また, セメント産業が処理 困難なリサイクル資源を積極的に活用していることの重み付けとし て，リサイクル率を用いた未利用率を用いた。リサイクルが困難な 廃棄物であるほどリサイクル率は低くなる, 寸なわち未利用率が高 くなると考えられる。そのため, 未利用率が高いリサイクル資源の 積極的な活用により指標值が高くなる, すなわち環境貢献となるこ とで，リサイクルの難しい資源の積極的な活用を表すことが出来る と考えられる。廃棄物指標を式(1)に, 未利用率の算出式を式(2)に示 す。セメント製造プロセスにおいては, 発生する廃棄物は生産量の 0.0005\%程度と極めて少ないことから ${ }^{10)}$ ，本研究ではリサイクル資 源の発生原単位 $c_{k}$ は無視した。そのため, セメントの $I_{W}$ はリサイ クル資源の使用原単位 $W_{k}$ と未利用率 $Y_{k}$ で算出可能である。また, 構造物を評価する際においても, 構造物のライフサイクルで発生す るリサイクル資源量を基に本評価式を適用した。
Table1 Values of $I W_{4}$ for recycling and disposal used in the previous method

\begin{tabular}{|c|c|c|c|c|}
\hline \multirow{2}{*}{} & \multicolumn{2}{|c|}{ Basic unit $(\mathrm{kg} / \mathrm{t})$} & $\begin{array}{c}\text { Unused rate } \\
(\%)\end{array}$ & $\begin{array}{c}I w_{4} \\
(\mathrm{~kg} / \mathrm{t})\end{array}$ \\
\cline { 2 - 3 } & $\mathrm{w}_{\mathrm{k}}$ & $\mathrm{c}_{\mathrm{k}}$ & 0 & 0 \\
\hline \hline Recycle & 1000 & 0 & 0 & -1000 \\
\hline Disposal & 0 & 1000 & 100 & \\
\hline
\end{tabular}

$$
\begin{aligned}
& I w_{4, m}=\sum \gamma_{k} \times\left(w_{k}-c_{k}\right) \\
& \gamma_{k}=100-R_{k} \\
& \text { ここに, } \\
& I w_{4, m}: \text { 構成材料 } \mathrm{m} \text { の廃棄物指標 }(\mathrm{kg} / \mathrm{t}) \\
& \gamma_{k}: \text { リイクル資源の未利用率 }(\%) \\
& R_{k} \text { : リサイクル資源 } \mathrm{k} \text { のリサイクル率 }(\%) \\
& w_{k}: \text { リサイクル資源 } \mathrm{k} \text { の使用原単位 }(\mathrm{kg} / \mathrm{t}) \\
& c_{k}: \text { リサイクル資源 } \mathrm{k} \text { の発生原単位 }(\mathrm{kg} / \mathrm{t})
\end{aligned}
$$

\section{2 既存の方法におけるシステム境界および課題点}

Fig. 1 に，これまでの検討 9)で実施した既存のシステム境界を示 す。検討範囲は「材料の製造」から解体発生物の「廃棄・リサイク ル」までとした。

解体後のマテリアルフローについて, 解体段階において「リサイ クル」と「廃棄」に分類され, それぞれのプロセスで廃棄/リサイク ル段階に移行すると設定した。そのため，I $W_{4}$ は，それぞれの排出 プロセスごとにそれぞれのリサイクル資源の使用・発生原単位と未 利用率を用いて算出される。また，解体段階で既に「リサイクル」 と「廃棄」に分類されていることから, 廃棄・リサイクル段階の排 出時における未利用率は, 解体発生物量の配分（リサイクル率）に 関わらず, リサイクルプロセスが $0 \%$, 廃棄プロセスが $100 \%$ となる。

すなわち,「リサイクル」については, リサイクルプロセスを通過 するリサイクル資源 $1000 \mathrm{~kg} / \mathrm{t}$ を 100\%利用して再生材としてリサイ クルされるため, リサイクル資源の使用原単位 $W_{k}$ は $1000 \mathrm{~kg} / \mathrm{t}$, 発 生原単位 $c_{k}$ は $0 \mathrm{~kg} / \mathrm{t}$ ，未利用率は $0 \%$ となる。一方「廃棄」について は, 廃㶳プロセスを通過するリサイクル資源 $1000 \mathrm{~kg} / \mathrm{t}$ を $100 \%$ 廃棄 し, 廃棄物として埋立てされるため, リサイクル資源の使用原単位 $W_{k}$ は $0 \mathrm{~kg} / \mathrm{t}$, 発生原単位 $c_{\mathrm{k}}$ は $1000 \mathrm{~kg} / \mathrm{t}$ ，未利用率は $100 \%$ となる。 既存の方法における $I W_{4}$ をTable1 に示す。

しかしながら, 既存の方法では, コンクリート塊の廃棄・リサイ クルにおけるリサイクル資源の原料が同一のコンクリート塊である ために未利用率も同一である心゙きにも関わらず，その未利用率が異 なっており，マテリアルフローとして整合性がないことが課題とし

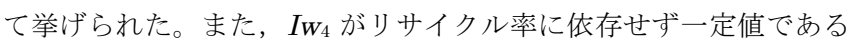
こと, 構造物の評価においてコンクリート塊の廃棄による負荷が著 しく大きくなり 9)，コンクリート塊のリサイクル率を考慮すると過 大評価している可能性があること等も課題として挙げられた。

\section{3 修正システム境界}

Fig. 2 に, 修正システム境界を示す。構造物の解体後の「廃棄・ リサイクル」段階においてコンクリート塊が解体発生物として発生 すると設定し, 廃棄量とリサイクル量はコンクリート塊のリサイク 


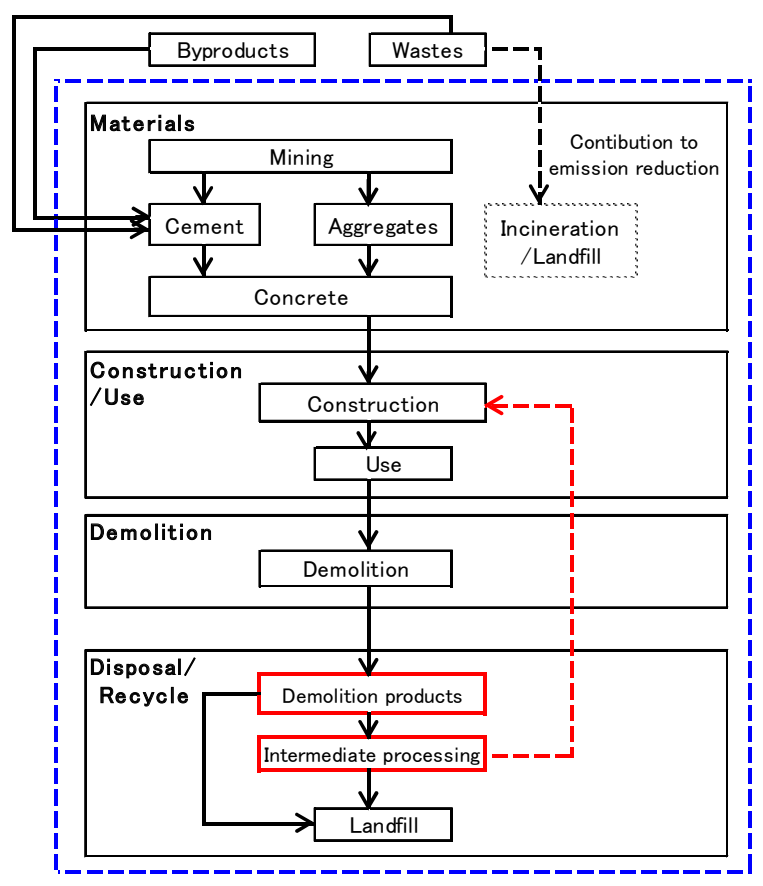

Fig. 2 Modified system boundary

ル率に従って配分することとした。すなわち，解体発生物の一部が 直接埋立て処理により廃棄され, 一部が中間処理後に埋立て処理に よる廃棄またはリサイクルされることとした。中間処理後のリサイ クル部分は路盤材としてシステム系内で処理されるとして評価しな かった。埋立て処理により廃棄される解体発生物をコンクリート塊 の未利用分とし， I $W_{4}$ を算出した。上記条件と寸ることで，コンク リート塊のリサイクル率が「廃棄」の $I W_{4}$ に直接反映されることと なる。

\section{4 「廃棄・リサイクル」の廃棄物指標の再評価結果}

Table2 に, 解体発生物のリサイクル率を任意に設定した場合の既 存および修正システム境界における「廃棄」段階の $I_{W}$ を示す。既 存の方法は, 前述したように廃棄プロセスのリサイクル資源を $100 \%$ 廃棄することから未利用率 $100 \%$ となり, 解体発生物のリサイ クル率に関わらず $I W_{4}$ は- $1000 \mathrm{~kg} / \mathrm{t}$ である。一方, 修正システム境 界による評価では, 未利用率に応じて $I W_{4}$ が変動する結果となった。 リサイクル率に応じた変動の程度は検討の余地があるものの, コン クリート塊の未利用率が小さくなるほど負の值である $I W_{4}$ の絶対值 は小さくなることから, 廃棄物の活用による環境負荷の低減が捉え られており, 修正システム境界の方が既存の方法より妥当性が高い と考えられる。

なお, 解体発生物の廃棄・リサイクルに関する $I W_{4}$ は, 未利用率 にリサイクル資源発生量を乗じた值であるために，見掛け上はリサ イクル率をダブルカウントしているような計算となる。しかしなが ら, これは解体発生物がコンクリート塊の単一材料であることや, リサイクル分が前述の通り評価されないことによる。

\subsection{LCA コストおよび LCC の算出方法}

\section{(1) 評価範囲および条件}

セメントは $1 \mathrm{t}$ あたり, コンクリートは床面積 $10 \mathrm{~m}^{2} \times$ 厚さ $0.1 \mathrm{~m}$ の無筋コンクリートを仮定し $1 \mathrm{~m}^{3}$ あたりの LCA コストおよび LCC
Table2 Values of $I w_{4}$ in disposal phase

\begin{tabular}{|c|c|c|c|c|c|c|}
\hline $\begin{array}{c}\text { Recycle ratio of } \\
\text { demolition product } \\
(\%)\end{array}$ & \multicolumn{3}{|c|}{ Previous method } & \multicolumn{3}{c|}{ Modified method } \\
\cline { 2 - 7 }$(\mathrm{kg} / \mathrm{t})$ & $\begin{array}{c}\text { Unused } \\
\text { rate }(\%)\end{array}$ & $\begin{array}{c}I W_{4} \\
(\mathrm{~kg} / \mathrm{t})\end{array}$ & $\begin{array}{c}C_{k} \\
(\mathrm{~kg} / \mathrm{t})\end{array}$ & $\begin{array}{c}\text { Unused } \\
\text { rate }(\%)\end{array}$ & $\begin{array}{c}I W_{4} \\
(\mathrm{~kg} / \mathrm{t})\end{array}$ \\
\hline \hline 0 & 1000 & 100 & -1000 & 1000.0 & 100 & -1000 \\
\hline 20 & 1000 & 100 & -1000 & 800.0 & 80 & -640 \\
\hline 40 & 1000 & 100 & -1000 & 600.0 & 60 & -360 \\
\hline 60 & 1000 & 100 & -1000 & 400.0 & 40 & -160 \\
\hline 80 & 1000 & 100 & -1000 & 200.0 & 20 & -40 \\
\hline 100 & 1000 & 100 & -1000 & 0.0 & 0 & 0 \\
\hline
\end{tabular}

Table3 Basic units of wastes and byproducts

\begin{tabular}{|c|c|c|c|c|}
\hline \multicolumn{2}{|c|}{ Category and items } & \multirow{2}{*}{$\begin{array}{l}\text { PC } \\
0.0\end{array}$} & \multirow{2}{*}{$\begin{array}{c}\text { BB } \\
432.7\end{array}$} & \multirow{2}{*}{$\begin{array}{c}\begin{array}{c}\text { Unused } \\
\text { rate } \\
(\%)\end{array} \\
0\end{array}$} \\
\hline \multirow{18}{*}{ 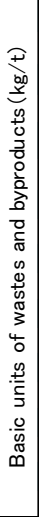 } & Blast furnace slag & & & \\
\hline & Fly ash & 0.0 & 0.0 & 0 \\
\hline & Coal ash & 127.1 & 72.1 & 2 \\
\hline & Sewage sludge, sludge & 51.2 & 29.1 & 25 \\
\hline & Byproduct gypsum & 33.6 & 29.1 & 0 \\
\hline & Waste soil from construction & 31.0 & 17.6 & 12 \\
\hline & Icineration ash, Soot, Dust & 25.7 & 14.6 & 29 \\
\hline & Non-ferrous slag & 12.7 & 7.2 & 8 \\
\hline & Wood chips & 10.8 & 6.1 & 6 \\
\hline & Foundry sand & 6.9 & 3.9 & 8 \\
\hline & Waste plastics & 10.5 & 5.9 & 27 \\
\hline & Steel slag & 6.8 & 3.9 & 8 \\
\hline & Waste oil & 5.4 & 3.1 & 9 \\
\hline & Waste white clay & 4.8 & 2.7 & 8 \\
\hline & Recycled oil & 3.3 & 1.9 & 9 \\
\hline & Waste tire & 1.2 & 0.7 & 27 \\
\hline & Meat and bone meal & 1.0 & 0.5 & 3 \\
\hline & Others & 10.3 & 5.8 & 5 \\
\hline & $I w_{4}(\mathrm{~kg} / \mathrm{t})$ & 34.1 & 19.4 & 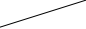 \\
\hline Bas & unit of $\mathrm{CO}_{2}$ emission $\left(\mathrm{kg}-\mathrm{CO}_{2} / \mathrm{t}\right)$ & 785 & 449 & 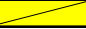 \\
\hline
\end{tabular}

を算出した。セメントの評価範囲は, Fig. 2 に示寸修正システム境 界内における「材料の製造」のセメントまでとした。コンクリート の評価範囲は「材料の製造」から「廃棄・リサイクル」までとした。 コンクリートの評価に関して, 本検討では構造物に必要な材料量の み考慮すること, 使用された材料は解体後に全てリサイクルまたは 埋立て処分されることとし,「施工」,「供用」,「解体」において廃棄 物は発生しないとした。また, 輸送に関する $\mathrm{CO}_{2}$ は考慮しなかった。

\section{（2）セメントの廃棄物指標および温暖化指標}

評価するセメントは PC および BB とし， BB 中の高炉スラグ微 粉末の混合率は $43.3 \%$ と仮定した。セメントの廃棄物指標は Table3 に示すセメントのリサイクル資源原単位および未利用率 10)を用い て式(1)で算出した值を, 温暖化指標は $\mathrm{CO}_{2}$ 排出量原単位を用いた。 なお，未利用率の算出に用いたリサイクル率は，既往の研究 ${ }^{12}$ にお いて廃棄物処理における減量化を考慮した式(3)で定義される $R_{\mathrm{k} 3}$ の 值を用いた。また, $\mathrm{CO}_{2}$ 排出量原単位は文献 10)に示す直接排出した $\mathrm{CO}_{2}$ に購入電力分を加えた值を用い, 購入電力から $\mathrm{CO}_{2}$ 排出量原単 位への変換には温室効果ガス排出量・報告・公表制度の代替值 $(2011)$ を用いた。セメントの廃棄物指標および $\mathrm{CO}_{2}$ 排出量原単位を Table3 に示す。

$$
\begin{aligned}
& R_{k 3}=A_{\text {recycle }} /\left(A_{\text {recycle }}+A_{\text {disposal }}\right) \times 100 \\
& \text { ここに, } \\
& A_{\text {recycle }}: \text { 再生利用量 }(\mathrm{kg}) \\
& A_{\text {disposal }}: \text { 最終処分量 }(\mathrm{kg})
\end{aligned}
$$


Table4 Mix proportions of concrete

\begin{tabular}{|c|c|c|c|c|c|}
\hline & \multicolumn{5}{|c|}{$\mathrm{kg} / \mathrm{m}^{3}$} \\
\cline { 2 - 6 } & Water & Cement & $\begin{array}{c}\text { Fine } \\
\text { aggregate }\end{array}$ & $\begin{array}{c}\text { Coarse } \\
\text { aggregate }\end{array}$ & $\begin{array}{c}\text { Chemical } \\
\text { admixture }\end{array}$ \\
\hline \hline PC & 184 & 323 & 940 & 881 & 3 \\
\hline BB & 182 & 319 & 921 & 898 & 3 \\
\hline
\end{tabular}

Table5 Details of demolition machines

\begin{tabular}{|c|c|c|c|c|}
\hline & Machine & Summary & Type & $\begin{array}{c}\text { Consumption rate } \\
(\mathrm{L} / \mathrm{h})\end{array}$ \\
\hline \hline \multirow{3}{*}{ Demolition } & $\begin{array}{c}\text { Base machine } \\
(\text { Backhoe })\end{array}$ & $0.8 \mathrm{~m}^{3}$ & Diesel & 16 \\
\cline { 3 - 5 } & $\begin{array}{c}\text { Concrete crushing } \\
\text { machine }\end{array}$ & $\begin{array}{c}\text { Crushing power } \\
549 \sim 981 \mathrm{kN}\end{array}$ & - & - \\
\hline $\begin{array}{c}\text { Accumulation } \\
\text { and loading }\end{array}$ & Backhoe & $0.8 \mathrm{~m}^{3}$ & Diesel & 16 \\
\hline
\end{tabular}

\section{（3）評価したコンクリートの概要}

使用材料は, セメントは PC および BB，骨材は天然細骨材およ び天然粗骨材とした。また, 調合条件は 24-18-20 とした。Table4 にコンクリート調合を示す。「施工」に関しては, 容量 $3.0 \mathrm{~m}^{3}$ のコ ンクリートミキサで生コンクリートが混練され， $3.0 \mathrm{~m}^{3}$ アジテータ 車で運搬後に人力で施工されることとした。なお，施工に関しては コンクリートミキサのみ考慮することとした。「解体」に関しては, 新・解体工法と積算 (2017 年発行) 13)および公共建築工事積算基準 平成 31 年版 ${ }^{14)}$ を参考にして圧砕工法を用いることとした。ベース マシンは $0.8 \mathrm{~m}^{3}$ のバックホウとし, 破壊力 $549 \sim 981 \mathrm{kN}$ のコンクリ 一ト圧砕機を取り付けて解体することとした。解体後はバックホウ により集積して搬出することとした。また，文献 ${ }^{14)}$ の作業能率およ

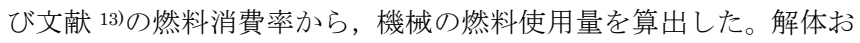
よび集積機械の詳細をTable5 に, 作業能率および燃料使用量を Table6 に示す。「廃棄・リサイクル」に関しては, 平成 30 年度建設 副産物実態調查を参考にし, 解体発生物のうち $99.3 \%$ 路盤材とし て再利用され， $0.7 \%$ が最終処分場に埋め立て処分されることとした。 また, 埋め立てられる $0.7 \%$ うち $0.5 \%$ は現場から直接安定型処分 場へ， $0.2 \%$ は間処理後に廃棄されることとした。

\section{(4) コンクリートの廃棄物指標および温暖化指標}

コンクリートの「材料の製造」から「廃棄」の各項目の廃棄物指 標 $I W_{4,1}$, は, 式(1)により算出した各項目内の構成材料に関する廃棄 物指標 $I W_{4, \mathrm{~m}}$ に構成材料の数量を乗じたものの総和として, 式(4)に より算出した。また, 廃棄物の排出に関する $I_{W}, 1$, ' は, 2.4 で示す 修正した $I_{W}$ を用いて算出した。システム境界内全体の廃棄物指標 は, 各項目の廃棄物指標 $I W_{4,1}$, の合計として算出した。システム境 界内全体の温暖化指標は, 式(5)により算出した「材料の製造」から 「廃棄・リサイクル」までの各項目の $\mathrm{CO}_{2}$ 排出量 $I g_{2,1}$ ' の合計とし て算出した。セメント以外の使用材料, 施工時のコンクリートミキ サおよび解体発生物の廃棄に関する $\mathrm{CO}_{2}$ 排出量原単位は文献 ${ }^{15)}$ の 值を用いた。解体に関する $\mathrm{CO}_{2}$ 排出量は, Table6 に示寸燃料使用量 に文献 $\left.{ }^{15}\right)$ に記載の $\mathrm{CO}_{2}$ 排出量原単位を乗じることで算出した。コン クリート塊のリサイクルに関する環境負荷はリサイクル先での使用 時に計上されるとし，本検討内では評価しなかった。なお，いずれ の $\mathrm{CO}_{2}$ 排出量原単位も, セメントの場合と同様に購入電力分を加え た值を用いた。Table7に, 構成材料に関する廃棄物指標および $\mathrm{CO}_{2}$
Table6 Working efficiency and fuel consumption

\begin{tabular}{|c|c|c|c|c|c|c|}
\hline & \multicolumn{3}{|c|}{ Working } & \multicolumn{3}{c|}{ Fuel } \\
\cline { 2 - 7 } & $\begin{array}{c}\text { Unit } \\
(*)\end{array}$ & $\begin{array}{c}\text { Efficiency } \\
(\text { day } / *)\end{array}$ & $\begin{array}{c}\text { Time } \\
(\text { day })\end{array}$ & Fuel type & $\begin{array}{c}\text { Consumption } \\
\text { rate } \\
(\mathrm{L} / \mathrm{h})\end{array}$ & $\begin{array}{c}\text { Consumption } \\
\text { amount } \\
(\mathrm{L})\end{array}$ \\
\hline \hline Demolition & $\mathrm{m}^{2}$ & 0.0345 & 0.345 & Diesel & 16 & 44.2 \\
\hline $\begin{array}{c}\text { Accumulation } \\
\text { and loading }\end{array}$ & $\mathrm{m}^{3}$ & 0.028 & 0.028 & Diesel & 16 & 3.58 \\
\hline
\end{tabular}

Table7 Waste indicators and $\mathrm{CO}_{2}$ emission units

\begin{tabular}{|c|c|c|c|}
\hline \multirow{2}{*}{$I_{2}$} & \multirow{2}{*}{$(\mathrm{kg} / \mathrm{t})$} & \multicolumn{2}{|c|}{$I g_{2}$} \\
\cline { 3 - 4 } & & Unit(*) & $\left(\mathrm{kg}-\mathrm{CO}_{2} / *\right)$ \\
\hline \hline $\mathrm{PC}$ & 34.1 & $\mathrm{t}$ & 768.1 \\
\hline BB & 19.4 & $\mathrm{t}$ & 437.4 \\
\hline Fine aggregate & 0.0 & $\mathrm{t}$ & 6.9 \\
\hline Coarse aggregate & 0.0 & $\mathrm{t}$ & 5.2 \\
\hline Rebar & 0.0 & $\mathrm{t}$ & 944.7 \\
\hline Concrete mixer & 0.0 & $\mathrm{~m}^{3}$ & 0.7 \\
\hline Diesel & 0.0 & $\mathrm{~L}$ & 2.6 \\
\hline Disposal & -0.1 & $\mathrm{t}$ & 1.6 \\
\hline
\end{tabular}

排出量原単位を示寸。

$$
\begin{aligned}
& I w_{4, l}{ }^{\prime}=\sum\left(M m \times I w_{4, m}\right) / 1000 \\
& I g_{2, l}{ }^{\prime}=\sum\left(M m \times I g_{2, m}\right) / 1000 \\
& \text { ここに, } \\
& I W_{4,1}{ }^{\prime}: \text { 項目 } 1 \text { の廃较物指標 }(\mathrm{t}) \\
& M m: \text { 構成材料 } \mathrm{m} \text { の使用量 }(\mathrm{t}) \\
& I g_{2, \mathrm{l}}{ }^{\prime}: \text { 項目 } 1 \text { の温暖化指標 }(\mathrm{t}) \\
& I g_{2, \mathrm{~m}} \text { : 構成材料 } \mathrm{m} \text { の } \mathrm{CO}_{2} \text { 排出量原単位 }(\mathrm{kg} / \mathrm{t})
\end{aligned}
$$

\section{（5）LCA コストの算出方法}

LCA コストは, セメントまたはコンクリートに関する廃棄物指標 $I W_{4,1}$ ' と温暖化指標 $I g_{2,1}$ ’を経済的指標で統合化することで算出し た。両指標の統合化は，それぞれの指標に重み $W_{3}$ および $G_{3}$ を乗じ たものの和として, 式(6)により算出した ${ }^{8)}$ 。重み $W_{3}$ および $G_{3}$ の定 義を式(7)および式(8)に示す。

重み付けに関しては, 廃棄物指標および温暖化指標ともに值が比 較的大きく, 一般的な建設材料である PC の環境影響を基準とした。 すなわち, 重み $W_{3}$ および $G_{3}$ は, $\mathrm{PC}$ の廃棄物影響および温暖化影 響を表す $E_{W 3}(\mathrm{PC})$ おび $E g_{3}(\mathrm{PC})$ をそれぞれ $\mathrm{PC}$ の廃棄物指標およ び $\mathrm{CO}_{2}$ 排出量原単位で除することで，PCで標準化した值とした。 $E_{W_{3}}(\mathrm{PC})$ および $E g_{3}(\mathrm{PC})$ にいては, 日本版被害算定型影響評価手 法 LIME3 の産業廃棄物および $\mathrm{CO}_{2}$ に関する統合化係数に，それぞ れ $\mathrm{PC}$ のリサイクル資源の使用原単位および $\mathrm{CO}_{2}$ 排出量原単位を乗 じることで，式(9)および式(10)により算出した。統合化係数とは, LIME3 において, 各種環境影響のインベントリから単一指標を得 るための係数である。LIME3 で統合化評価を行う場合には, 環境 負荷物質ごとにそれぞれの統合化係数を用いて評価を行う。本研究 では簡易化のため, 廃棄物の重み付けに関しては, ポルトランドセ メントで最も活用量の多い石炭灰に対応する産業廃棄物 (ばいじん) の值 $(0.201 \mathrm{US} \$ / \mathrm{kg})$ を用いた。なお，活用量が二番目に多い産業 廃棄物（污泥）では $0.253 \mathrm{US} \$ / \mathrm{kg}$, 活用量が三番目に大きい一般廃 棄物（覆土）では $0.175 \mathrm{US} \$ / \mathrm{kg}$ であり, 本研究で用いた産業廃棄物 
（ばいじん）の值との差はそれほど大きくない。温暖化指標につい ては地球温暖化 $\left(\mathrm{CO}_{2}\right)$ の值 $(0.017 \mathrm{US} \$ / \mathrm{kg})$ を用いた。なお，リ サイクル資源の使用は環境貢献であるため式(6)右辺の第 1 項は正 の值, $\mathrm{CO}_{2}$ 排出は環境負荷であるため式(6)右辺の第 2 項は負の值と なる。また, LIME3 の統合化係数を用いた場合, 指標值が US $\$$ と して算出されるため, 1US\$あたり 100yen として日本の通貨に換算 した。

$$
\begin{aligned}
& I_{l}=W_{3} \times I w_{4, l}{ }^{\prime}+G_{3} \times I g_{2, l}{ }^{\prime} \\
& W_{3}=E w_{3}(\mathrm{PC}) / I w_{4}(\mathrm{PC}) \times 1000 \\
& G_{3}=E g_{3}(\mathrm{PC}) / I g_{2}(\mathrm{PC}) \times 1000 \\
& E w_{3}(\mathrm{PC})=\text { 統合化係数 }(\text { 産業廃棄物 }(\text { ばいじん })) \\
& \quad \times \text { リサイクル資源の使用原単位 }(\mathrm{PC}) \times 100 \\
& E g_{3}(\mathrm{PC})=\text { 一統合化係数 }\left(\mathrm{CO}_{2}\right) \\
& \quad \times C O_{2} \text { 排出量原単位 }(\mathrm{PC}) \times 100
\end{aligned}
$$

ここに,

$I_{1}:$ 項目 1 の LCA コスト (yen)

$W_{3}: \mathrm{PC}$ で標準化した廃棄物指標に関する重み (yen/t)

$G_{3}: \mathrm{PC}$ で標準化した温暖化指標に関する重み (yen/t)

$E_{W_{3}}(\mathrm{PC}): \mathrm{PC}$ の廃棄物影響 (yen/t)

$I_{W}(\mathrm{PC}) ： \mathrm{PC}$ の廃棄物指標（kg/t)

$E g_{3}(\mathrm{PC}): \mathrm{PC}$ の温暖化影響 (yen/t)

$I g_{2}(\mathrm{PC}): \mathrm{PC}$ の $\mathrm{CO}_{2}$ 排出量原単位 $(\mathrm{kg} / \mathrm{t})$

\section{6 セメントの LCC 算出方法}

セメントについてはセメントの販売価格とし, 文献(建設物価 平 成 30 年 2 月版） 16)における「セメント (バラ)」価格の 47 都道府 県主要地の平均值を用いた。

\section{7 コンクリートの LCC 算出方法}

コンクリートについて，「材料の製造」に関する費用は生コンクリ

一トの販売価格とし, 文献 ${ }^{15)}$ における価格の 47 都道府県主要地の 平均值を用いた。

「施工」に関する費用は，文献 14)に記載の「小型構造物（工作物 の基礎等)」のコンクリート打設に係る歩掛に施工数量および単価を 乗じることで算出した。Table8に，単位容積あたりの施工単価の詳 細を示す。「特殊作業員」の単価は文献 16)における価格の 47 都道府 県主要地の平均值を用い,「その他」については, 文献 14)に従い「特 殊作業員」の価格の $25 \%$ を適用した。

「解体」に関する費用は, 文献 ${ }^{14)}$ に記載の「上部躯体とりこわし」 の歩掛に施工数量を乗じることで算出した。Table9に, 単位面積当 たりの解体単価の詳細を示す。「ベースマシン運転」の単価は文献 14)に記載の表 RA-22-6 および別表 RA-22-6-1，文献 14)，17)を用いて 算出した。「コンクリート圧砕機」の単価は文献 13)の值を, 「普通作 業員」の単価は文献 16)における価格の 47 都道府県主要地の平均値 を用い，「その他」については文献 14)に従い「普通作業員」の 25\% の価格を用いた。解体後のコンクリート塊の集積に関しては, 文献

\begin{tabular}{|c|c|c|c|c|c|c|c|}
\hline & & Summary & $\begin{array}{l}\text { Unit } \\
(*)\end{array}$ & $\begin{array}{c}\text { Unit cost } \\
\text { (yen } / *)\end{array}$ & $\begin{array}{c}\text { Productivity } \\
\left(* / \mathrm{m}^{2}\right)\end{array}$ & $\begin{array}{c}\text { Cost } \\
\left(y e n / m^{2}\right)\end{array}$ & $\begin{array}{l}\text { Total cost } \\
\left(\text { yen } / \mathrm{m}^{2}\right)\end{array}$ \\
\hline \multirow{4}{*}{ Demolition } & $\begin{array}{c}\text { Driving of } \\
\text { base machine }\end{array}$ & $\begin{array}{c}\text { Backhoe } \\
0.8 \mathrm{~m}^{3}\end{array}$ & day & 75,771 & 0.0345 & 2,614 & \multirow{4}{*}{4,277} \\
\hline & $\begin{array}{l}\text { Concrete } \\
\text { crushing } \\
\text { machine }\end{array}$ & $\begin{array}{c}\text { Crushing } \\
\text { power } \\
549 \sim 981 \mathrm{kN}\end{array}$ & day & 17,900 & 0.0345 & 618 & \\
\hline & $\begin{array}{l}\text { Normal } \\
\text { worker }\end{array}$ & & Person & 24,247 & 0.0345 & 837 & \\
\hline & Other & & set & & 1 & 209 & \\
\hline
\end{tabular}
15)に記載の「コンクリート類集積積込」の歩掛にバックホウの運転 単価を乗じることで算出した。バックホウの運転単価はベースマシ ン運転と同様の方法で算出した。Table10 に単位容積あたりのコン
Table8 Construction unit cost

\begin{tabular}{|c|c|c|c|c|c|}
\hline & $\begin{array}{c}\text { Unit } \\
(*)\end{array}$ & $\begin{array}{c}\text { Unit cost } \\
(\text { yen } / *)\end{array}$ & $\begin{array}{c}\text { Productivity } \\
\left(* / \mathrm{m}^{3}\right)\end{array}$ & $\begin{array}{c}\text { Cost } \\
\left(\mathrm{yen} / \mathrm{m}^{3}\right)\end{array}$ & $\begin{array}{c}\text { Construction } \\
\text { cost } \\
\left(\mathrm{yen} / \mathrm{m}^{3}\right)\end{array}$ \\
\hline \hline $\begin{array}{c}\text { Special } \\
\text { worker }\end{array}$ & Person & 28,160 & 0.65 & 18,304 & \multirow{2}{*}{25,344} \\
\cline { 1 - 4 } Other & Set & 7,040 & 1 & 7,040 & \\
\hline
\end{tabular}

Table9 Demolition unit cost

Table10 Accumulation and loading unit cost

\begin{tabular}{|c|c|c|c|c|c|}
\hline & Summary & $\begin{array}{c}\text { Unit } \\
(*)\end{array}$ & $\begin{array}{c}\text { Unit } \\
\text { cost } \\
(\text { yen } / *)\end{array}$ & $\begin{array}{c}\text { Productivity } \\
\left(* / \mathrm{m}^{3}\right)\end{array}$ & $\begin{array}{c}\text { Cost } \\
\left(\mathrm{yen} / \mathrm{m}^{3}\right)\end{array}$ \\
\hline \hline $\begin{array}{c}\text { Driving of } \\
\text { backhoe }\end{array}$ & $0.8 \mathrm{~m}^{3}$ & day & 75,771 & 0.028 & 2,122 \\
\hline
\end{tabular}

Table11 Intermediate processing and final disposal unit cost

\begin{tabular}{|c|c|}
\hline \multicolumn{2}{|c|}{ Cost (yen/t) } \\
\hline $\begin{array}{c}\text { Intermediate } \\
\text { processing }\end{array}$ & Final disposal \\
\hline Concrete lump & Stable landfill \\
\hline \hline 2,913 & 12,333 \\
\hline
\end{tabular}

クリート塊集積の費用を示す。解体後に廃棄・リサイクルされるコ ンクリート塊の費用について, 中間処理費には最終処分費も含まれ る。そのため, 平成 30 年度建設副産物実態調査を参考にして廃棄 分の費用を配分した。すなわち, 現場から最終処分場に直接廃棄さ れる $0.5 \%$ 分は最終処分費とし，再資源化処理に廃棄される $0.2 \%$ 分 は中間処理費とした。

中間処理費は，文献 ${ }^{16)}$ に記載の中間処理受託料金におけるコンク リート塊（無筋・ $30 \mathrm{~cm}$ 以下）の各県の平均值を用いた。なお，文 献 14)には関東地方の料金のみ記載されており, 杤木県については下 限值しか記載されていなかった。中間処理費をTable11 に示す。廃 棄に関する費用は, 最終処分費用として文献 16)における最終処分受 託料金の安定型処分場の值を用いた。なお，文献 16)には関東地方に おける茨城県, 群馬県および千葉県の下限值のみの記載であったた め, それらの平均值を用いた。最終処分費をTable11に示す。

\section{8 フルコストによる総合評価}

$\mathrm{LCA}$ コストと LCC の和をフルコストとして算出して総合評価を 行った。なお，LCC は負荷としてマイナスの值とした。

\subsection{LIME3 による評価結果との比較}

既存の LCA 手法である LIME3 を用いて算出した LCA コストと 2.6 おび 2.7 において算出した LCC の和によりフルコストを算出 し, 前節までで提案した方法で算出したフルコストと比較を行った。 LIME3 による LCA コストの算出は, 各セメントの原料原単位, リ 
Table12 Value of $I w_{4}$ and $I g_{2}$ for portland blast-furnace slag cement

\begin{tabular}{|c|c|c|c|}
\hline & BA & BB & BC \\
\hline \hline$I W_{4}(\mathrm{~kg} / \mathrm{t})$ & 27.3 & 19.4 & 12.0 \\
\hline$I g_{2}\left(\mathrm{~kg}-\mathrm{CO}_{2} / \mathrm{t}\right)$ & 626 & 437 & 280 \\
\hline
\end{tabular}

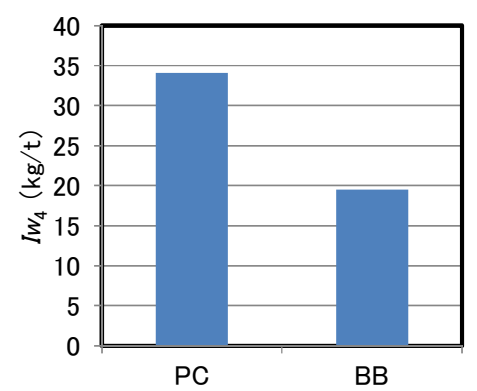

Fig. $3 I W_{4}$ of $P C$ and $B B$

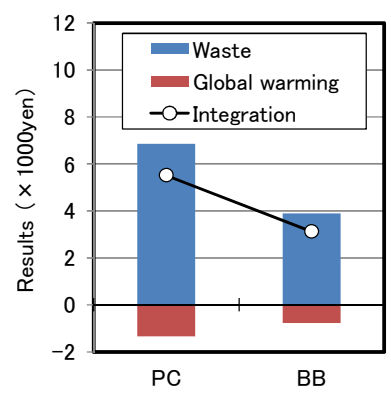

Fig. 4 LCA cost of cement

サイクル資源量, 環境負荷物質発生量, 購入電力などのインベント リデータに LIME3 の統合化係数を乗じることで得られた值の総和 により算出した。インベントリデータは本研究で提案する指標の算 出に用いたデータと同じものを用いた。

なお，本検討における「廃棄物」と「副産物」の扱いについては 既往の報告 11 ) と同様の方法で分類した。「廃棄物」に分類される品 目はセメントが受け入れることで埋立を回避したものとみなし環境 に貢献することとした。一方で, 「副産物」に分類される品目（本検 討では, 高炉スラグ微粉末, 副産石こう, 再生砕石）は一般に有償 であり，製品として消費されることが前提と考えられるため，埋立 回避による貢献は考慮しなかった。

\section{10 高炉セメントを用いたコンクリートの評価}

2.1 から 2.8 までの方法を用いて, 高炉セメントを用いたコンク リートの評価を行った。高炉セメントは A 種（以下， BA）, B 種, C 種 (以下, BC) とし, 高炉スラグ微粉末の混合率はそれぞれ $20 \%$, 43.3\%，65\%とした。高炉セメントを用いたコンクリートの調合は BB を使用した場合と同一とした。コンクリートの LCC について, $\mathrm{BA}$ および BC は建設物価に価格の記載がなかったが，製造や物流 の条件が価格に影響することが考えられたものの，本検討では便宜 上 BB と同様の值を用いた。Table12 に, 各高炉セメントの $I_{W_{4}}$ お よび $g_{2}$ を示す。

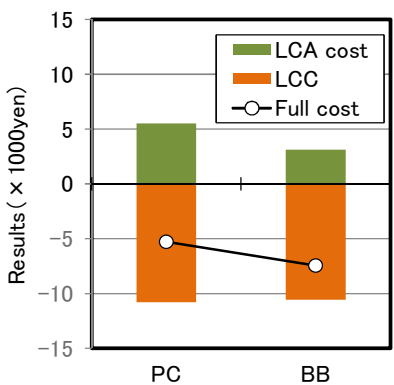

Fig. 5 Full cost of cement

Table13 Detail for the full costs of cement

\begin{tabular}{|c|c|c|c|}
\hline \multicolumn{2}{|c|}{} & PC & BB \\
\hline \hline \multirow{3}{*}{$\begin{array}{c}\text { Results } \\
\text { (yen) }\end{array}$} & LCA cost & 5,516 & 3,125 \\
\cline { 2 - 4 } & LCC & $-10,802$ & $-10,578$ \\
\cline { 2 - 4 } & Full cost & $-8,329$ & $-9,181$ \\
\hline \multicolumn{2}{|c|}{ LCA cost/LCC } & 0.51 & 0.30 \\
\hline
\end{tabular}

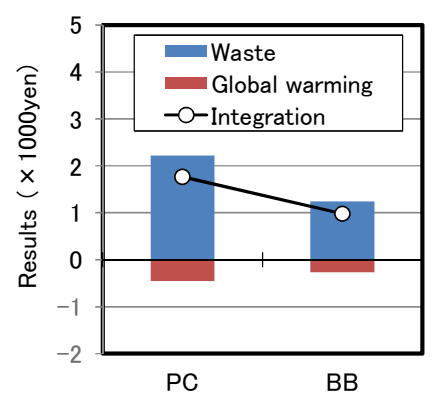

Fig. 6 LCA cost of concrete

\section{3. 結果}

\section{1 セメントの廃棄物指標}

Fig. 3 に, PC および BB の廃棄物指標を示す。廃棄物指標は PC の方が BB より高かった。これは，PC の方がリサイクル資源のう ち処理困難な廃棄物を大量に活用していることを表している。

\section{2 セメントの評価結果}

Fig. 4 に，セメントの LCA コストを示す。廃棄物活用に関する貢 献が $\mathrm{CO}_{2}$ 排出に関する負荷を上回り, 総合的には貢献側の值となっ た。また, PC の方が BB より貢献側に大きい值を示した。Fig. 5 に, セメントのフルコストを, Table13 にフルコストの詳細を示寸。セ メントの LCC の負荷は BBの方が PCより若干小さかった。一方で, $\mathrm{LCA}$ コストは PC の方が BB より貢献側に大きいことから, フルコ ストでは PC の方が BB より貢献側に大きかった。そのため, 環境 側面のコストを含めて考慮すると, PC の方が $\mathrm{BB}$ より優位である ことが示された。また，LCC の負荷に対する LCA コストの貢献の 比率も $\mathrm{PC}$ の方が $\mathrm{BB}$ より大きかったことや, PC と比較して BB の 方がフルコストの比率が 10\%程度大きかったことから，PC の方が コスト面において合理的であると考えられる。

\section{3 コンクリートの評価結果}

Fig. 6 に, コンクリートの LCA コストを示す。セメントと同様に 総合的には貢献側の值を示し，PC の方が BB より大きい值を示し た。Fig. 7 にコンクリートのフルコストを, Table14 にフルコストの 


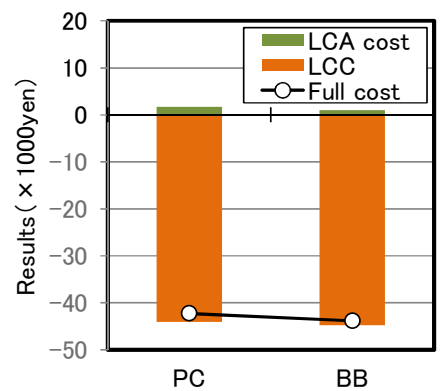

Fig. 7 Full cost of concrete

Table14 Detail for the full costs of concrete

\begin{tabular}{|c|c|c|c|}
\hline \multicolumn{2}{|c|}{} & PC & BB \\
\hline \hline \multirow{2}{*}{$\begin{array}{c}\text { Results } \\
\text { (yen) }\end{array}$} & LCA cost & 1,763 & 978 \\
\cline { 2 - 4 } & LCC & $-44,037$ & $-44,819$ \\
\cline { 2 - 4 } & Full cost & $-42,274$ & $-43,841$ \\
\hline \multicolumn{2}{|c|}{ LCA cost/LCC } & 0.040 & 0.022 \\
\hline
\end{tabular}
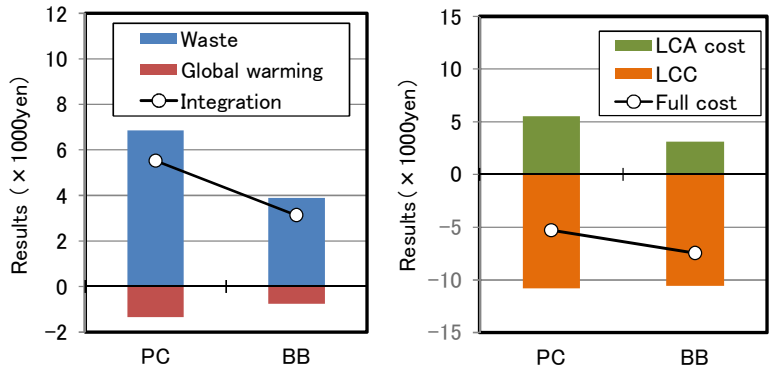

Fig. 8 LCA costs and full cost of cement by LIME3

(left: LCA cost, right: full cost)

詳細を示す。評価結果は PC の方が BB より貢献側に大きくなり, セメントの評価結果と同様の傾向となった。また, PC を使用した 場合のフルコストは BB を使用した場合より約 4\%縮減可能である ことが示された。一方で，LCC に対する LCA コストの比率や PC と BB のフルコストの比率はセメントの場合より著しく小さかった。 これは, LCA コストの主要な構成要素はセメントであり, コンクリ ートではセメントの影響が希勫されて小さくなったことが要因であ る。

\section{4 LIME3 との比較}

LIME3 を用いて評価した LCA コストおよびフルコストについて， セメントの結果をFig. 8 に, コンクリートの結果をFig. 9 に示す。 セメント, コンクリートいずれも, LCA コストやフルコストの評価 值およびその内訳は廃棄物指標を用いた場合とほぼ同值であり整合 的な結果が得られた。このことから, 本研究で提案する評価方法は, リサイクル資源の使用・発生原単位と未利用率を用い，比較的簡便 に妥当性のある指標值を示すことが出来ると考えられる。

\section{5 高炉セメントを使用したコンクリートの評価結果}

Fig. 10 にフルコストを, Table15にフルコストの詳細を示す。高 炉スラグ微粉末の混合率が多いほど LCA コストは低くなり, フル コストも負荷側に大きくなった。LCC 負荷に対する LCA コストの
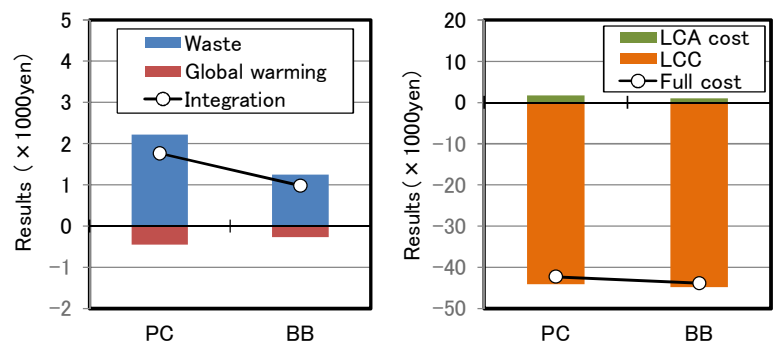

Fig. 9 LCA cost and full cost of concrete by LIME3 (left: LCA cost, right: full cost)

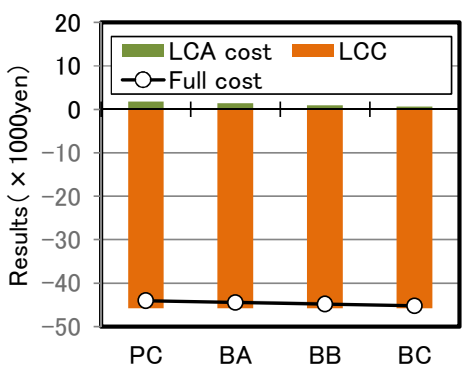

Fig. 10 Full costs of concrete using portland blast-furnace slag cement

Table15 Detail for the full costs of concrete using portland blast-furnace slag cement

\begin{tabular}{|c|c|c|c|c|c|}
\hline \multicolumn{2}{|c|}{} & PC & BA & BB & BC \\
\hline \hline \multirow{2}{*}{$\begin{array}{c}\text { Results } \\
\text { (yen) }\end{array}$} & LCA cost & 1,763 & 1,379 & 978 & 594 \\
\cline { 2 - 6 } & LCC & $-45,800$ & $-45,797$ & $-45,797$ & $-45,797$ \\
\cline { 2 - 6 } & Full cost & $-44,037$ & $-44,418$ & $-44,819$ & $-45,203$ \\
\hline \multicolumn{2}{|c|}{ LCA cost/LCC } & 0.038 & 0.030 & 0.021 & 0.013 \\
\hline
\end{tabular}

貢献の比率も 0 に近付くことから，フルコストで評価する場合，高 炉スラグ微粉末の混合率の増大は不利となることが示された。

\section{4. まとめ}

筆者らが提案した廃棄物指標を用い, 経済影響を考慮したコンク リートの環境影響評価を実施した結果，以下の知見が得られた。

(1)構造物解体後の廃棄に関して廃棄物指標を再検討した結果, 既存 の方法より妥当性が高いことが示された。

(2)セメントおよびコンクリートについて環境的側面と経済的側面 を考慮したフルコストで評価した結果，ポルトランドセメントの方 が高炉セメント B 種より有利であることが示された。

(3)コンクリートの環境影響に関するコストは, ライフサイクルコス トより著しく小さかった。

(4)高炉セメント A 種， B 種および C 種を用いたコンクリートにつ いてフルコストで評価した結果, 高炉スラグ微粉末の混合率の増大 は不利になることが示された。

なお，本検討で用いた廃棄物指標は現状のリサイクル資源の使用 量およびリサイクル率を用いて算出した值であり, リサイクル資源 の活用状況によっては評価值が変動することに留意する必要がある。 


\section{謝辞}

本研究の実施にあたっては, 広島大学の室園環氏, 太平洋セメン 卜 (株)の星野清一氏, 平尾宙氏，上野直樹氏，内田俊一郎氏，（株） トクヤマの茶林敬司氏にも多大なご助言を頂きました。記して謝意 を示します。

\section{参考文献}

1) Ministry of Economy, Trade and Industry: The Guide for SDG Business Management, 2019.5

経済産業省 : SDGs 経営ガイド, 2019.5

2) Itsubo, N.: Environmental management method orienting life cycle. From LCA to LCC and LCM-, Journal of the Society of Instrument and Control Engineers, Vol.43, No.5, pp.407-414, 2004.5 伊坪徳宏: ライフサイクルを指向した環境経営管理手法-LCAから LCC, LCM へ一, 計測と制御, 第 43 巻, 第 5 号, pp.407-414, 2004.5

3) Tokashiki, M.: Life cycle cost, Journal of the Association of Rural Planning, Vol.18, No.1, pp.66-67, 1999.6

渡嘉敷勝: ライフサイクルコスト, 農村計画学会誌, Vol.18, No.1, pp.66-67, 1999.6

4) Kobayashi, M., Ishizaka, K., Itsubo, N.: Lifecycle impact assessment and full cost assessment for IC package by LIME, Journal of the Reliability Engineering Association of Japan, Vol.31, No.6, pp.481-492, 2009

小林充，石坂和明，伊坪徳宏 : LIME を用いた IC パッケージのライフサ イクル影響評価とフルコスト評価, REAJ 誌, Vol.31, No.6, pp.481-492, 2009

5) Koseki, Y., Itsubo, N.: A preliminary study of life cycle based cost benefit analysis for water purifier as an adaptation of climate change, Proceedings of the 12th Meeting of the Institute of Life Cycle Assessment, pp.84-85, 2017.3

小関康雄, 伊坪徳宏 : 気候変動適応策としての浄水器を対象とした費用便 益分析, 第 12 回 LCA 学会研究発表会講演要旨集, pp.84-85, 2017.3

6) Koseki, Y., Itsubo, N.: A trial study of Marginal Abatement Costs Analysis for Climate Change Mitigation Strategies using Life cycle assessment, Proceedings of the 11th Meeting of the Institute of Life Cycle Assessment, pp.296-297, 2016.3

小関康雄, 伊坪徳宏 : LCA を活用した気候変動緩和策の限界削減費用分析 評価の一試行, 第 11 回 LCA 学会研究発表会講演要旨集, pp.296-297, 2016.3

7) Kirino, Y., Hoshinno, S., Chabayashi, T., Kawai, K.: Life cycle assessment of cement considering resource recycling - (Part 1) Life cycle assessment of cement using large amount wastes, Proceeding of the 72th Annual Meeting of Cement and Concrete Engineering, pp.128-129, 2018

桐野裕介, 星野清一, 茶林敬司, 河合研至 : セメントのリサイクル資源活 用を考慮した環境影響評価（その 1 ）廃棄物多量活用セメントの環境影響 評価, 第 72 回セメント技術大会講演要旨, pp.128-129, 2018

8) Kirino, Y., Kawai, K., Hirao, H., Shinmi, T.: Life cycle assessment of cement considering resource recycling - (Part 2) Integration method for wastes recycling and $\mathrm{CO}_{2}$ emission, Proceeding of the 72th Annual Meeting of Cement and Concrete Engineering, pp.130-131, 2018 桐野裕介, 河合研至, 平尾宙, 新見龍男 : セメントのリサイクル資源活用 を考慮した環境影響評価（その 2 ）廃棄物活用と CO2 排出の統合化手法の 検討, 第 72 回セメント技術大会講演要旨, pp.130-131, 2018

9) Shinmi, T., Kirino, Y., Chabayashi, T., Kawai, K.: Life cycle assessment of cement considering resource recycling - (Part 7) Evaluation of structure considering life cycle by waste indicator, Proceeding of the 73th Annual Meeting of Cement and Concrete Engineering pp.100-101, 2019

新見龍男, 桐野裕介, 茶林敬司, 河合研至 : セメントのリサイクル資源活 用を考慮した環境影響評価（その 7 ）構造物のライフサイクルを考慮した 廃棄物指標による評価, 第 73 回セメント技術大会講演要旨, pp.100-101, 2019

10) Japan Cement Association: The summary of LCI data for cement, 2019
セメント協会 : セメントの LCI データの概要， 2019

11) Kirino, Y., Hoshino, S., Kawai, K., Itsubo, N.: Life cycle assessment of cement considering resource recycling - (Part 10) Evaluation of cement considering environmental condition of each countries in the world, Proceeding of the 73th Annual Meeting of Cement and Concrete Engineering pp.106-107, 2019

桐野裕介, 星野清一, 河合研至, 伊坪徳宏 : セメントのリサイクル資源活 用を考慮した環境影響評価（その１０）各国の環境条件を反映したセメン 卜の評価, 第 73 回セメント技術大会講演要旨, pp.106-107, 2019

12) Shibazaki, Y., Kawai, K., Kirino, Y., Shinmi, T.: Life cycle assessment of cement considering resource recycling - (Part 8) Effect of difference of weighting method on evaluation values, Proceeding of the 73th Annual Meeting of Cement and Concrete Engineering pp.102-103, 2019 柴崎悠吾, 河合研至, 桐野裕介, 新見龍男：セメントのリサイクル資源活 用を考慮した環境影響評価（その 8 ）重み付けの相違が各種セメントの指 標值に及ぼす影響, 第 73 回セメント技術大会講演要旨, pp.102-103, 2019

13) Society of Demolition Method; New - demolition method and cost estimate, 2017 解体工法研究会 : 新 - 解体工法と積算, 2017

14) Research Institute on Building Cost; Public building construction cost estimate standard - 2019 Version, 2019 建築コスト管理システム研究所 : 公共建築工事積算基準 平成 31 年版, 2019

15) Japan Society of Civil Engineers; Concrete engineering series 62 Environmental impact assessment of concrete - Part 2, 2004 土木学会 : コンクリート技術シリーズ 62 コンクリートの環境負荷評価 (その 2 ), 2004

16) Construction Research Institute; Prices of construction materials and wages - February 2018 version, 2018 建設物価調查会 : 建設物価 平成 30 年 2 月版, 2018

17) Japan Construction Machinery and Construction Association; Construction equipment ownership cost list - 2018 Version, 2018 日本建設機械施工協会 : 平成 30 年度版 建設機械等損料表, 2018 


\author{
Tatsuo SHINMI ${ }^{* 1}$, Yusuke KIRINO $^{* 2}$, Hiroyoshi Kato ${ }^{* 3}$ \\ and Kenji KAWAI*4 \\ ${ }^{11}$ Cement Development Dept., Tokuyama Co., M.Eng. \\ ${ }^{2}$ Central Research Laboratory, Taiheiyo Cement Co., Dr.Sc. \\ ${ }^{3}$ Leader, Cement Development Dept., Tokuyama Co., Dr.Eng. \\ ${ }^{4}$ Prof., Graduate School of Advanced Science and Engineering, Hiroshima University, Dr.Eng.
}

To achieve sustainable development goals (SDGs), corporate activities considering social and environmental aspects are required and life cycle assessment (LCA) is conducted in many companies. However, the LCA includes only environmental aspects in many cases, and evaluation using economic indicators is also necessary for decision-making in corporate activities. Recently life-cycle cost (LCC) attracts attention as an evaluation of economic aspects and it is important to comprehensively evaluate LCA and LCC in order to achieve SDGs.

The authors have so far developed a waste indicator that can evaluate the use of recyclable resources (wastes and byproducts) in cement manufacture and also an integration method for comprehensive evaluation of wastes, byproducts, and $\mathrm{CO}_{2}$ emissions. In addition, the LCA of a concrete structure was conducted considering cement manufacture to the demolition and disposal of the structure as its life cycle. An integrated evaluation including economic indicators was also carried out by using the integration coefficients of the Life-cycle Impact Assessment Method Based on Endpoint Modeling (LIME3), which has been developed in Japan. The results showed that the evaluation value for ordinary portland cement was higher than that for portland blast-furnace slag cement type B.

In the present study, the environmental impact assessment of cement and concrete was performed considering economic aspects and full cost which is the sum of LCA cost and LCC was calculated. The relationship between the LCA cost and LCC was then discussed.

The LCA costs of cement and concrete were calculated from the integration of the waste indicator and global warming indicator by using the integration coefficients of LIME3 as an economic indicator. In the calculation of the LCC, market prices were used for cement, concrete constituents, and intermediate processing and disposal of demolished concrete. Construction and demolition costs were based on the estimation standard. The full cost was calculated as the sum of the LCA cost and LCC.

As a result, for both cement and concrete, the full cost for ordinary portland cement was lower than that for portland blast-furnace slag cement type B. The LCA cost was significantly lower than the LCC for concrete. Besides, for concrete using portland blast-furnace slag cement, the increase in the ground granulated blast-furnace slag content increased the full cost of the cement.

(2021 年 2 月 5 日原稿受理, 2021 年 6 月 22 日採用決定) 